Bulgarian Academy of Sciences. Space Research and Technology Institute. Aerospace Research in Bulgaria. 32, 2020, Sofia

DOI: https://doi.org/10.3897/arb.v32.e13

\title{
QUANTITATIVE ASSESSMENT OF PILOTING TECHNIQUE BY FLIGHT DATA RECORDER
}

\author{
Assen Marinov ${ }^{1}$, Georgi Yordanov ${ }^{2}$, Martin Kambushev ${ }^{1}$, \\ Stefan Biliderov ${ }^{I}$, Kiril Kambushev ${ }^{I}$ \\ ${ }^{\text {I} A v i a t i o n ~ F a c u l t y, ~ N a t i o n a l ~ M i l i t a r y ~ U n i v e r s i t y ~}$ \\ ${ }^{2}$ Bulgarian Air Force \\ e-mail:asen_aerodynamics@abv.bg
}

Keywords: Aircraft, Piloting Technique, Flight Activity, Flight Data Recorder

\begin{abstract}
Flight training is a complex and responsible training process for pilot and requires experienced specialists, good organization and quality control of flight activity. Its main purpose is to create highly qualified personnel with long-term professional skills in the techniques of piloting, aircraft flying and the combat use of aircraft.

Assessment is an important part of the training process for young cadets. It determines the extent to which trainees have been able to perceive, learn and comprehend their new flying activity and their ability to apply the acquired knowledge in tense conditions. Assessment is directly related to the quality of the flight training, and it should show the trainees the mistakes they have made and encourage them to upgrade their knowledge and skills. The trainees should be well versed in the assessment methodology and understand its purpose, otherwise the grades obtained will not be an indicator of their ability.
\end{abstract}

\section{Introduction}

The high quality of training requires continuous improvement of the methodology for flight preparation and the use of modern technical means. The use of computer-based training tools and automated training systems have become important nowadays.

In order to determine the knowledge gained and the level of training, trainees should be assessed. Assessment is complex and involves assessing their theoretical knowledge, their practical skills, and their physical endurance and discipline.

Evaluation of the piloting technique is of paramount importance in forming the final assessment of the trainee. It is done after each flight, evaluating all the elements of the exercise. The rating is the arithmetic mean of the assigned performance estimates and has a different weight depending on the type of flight. For this purpose, an assessment sheet is completed, which together with other 
documentation related to flight task is stored in student's personal file. The overall rating of the piloting technique is the arithmetic mean of the estimates of each flight.

The evaluation of the piloting technique by flight data recorder is performed on two levels - qualitative analysis of the elements of the exercise and quantitative assessment. Important for its determination are the records of parameters - speed, height and load factor.

Qualitative analysis includes:

- determining flight stages;

- defining completed elements;

- the order of completion of the assignment;

- determining the deviations and errors in the piloting technique.

In the quantification of the piloting technique, each element is evaluated as values of the recorded parameters, at certain stages of the executed element (the socalled control points), are compared with the set ones. Any deviations of parameters from setpoints are determined and evaluated accordingly.

In order to maintain the high quality of the training and to ensure that the assessment is correct, the training methodology must be continuously improved and assessment optimized. The main steps to increase the level of the training are:

- updating of the manuals regulating flight activity;

- realism, efficiency and flexibility in preparation;

- clear training methodology;

- up-to-date and accessible training programs;

- use of modern computer systems;

- use of flight simulators;

- clear standards for the evaluation of piloting techniques;

- updated student evaluation criteria;

- quality control.

\section{Main purpose of optimization of flight technique' assessment}

The main goal in optimizing the assessment of piloting techniques is to reduce the subjective factor in evaluating learners and improve the quality of training, using modern computer models and applications. The subjective factor can be reduced by correctly assessing the accomplished elements of the flight task in accordance with the approved assessment standards. Doing this after each flight (during the analysis of the exercise performed) or at the end of the flight, facilitates the work of the instructor staff.

In order to achieve this goal, the following main tasks must be accomplished: 
- to create a computer application for research and storage of the data recorded by the aircraft flight data recorder;

- to create an algorithm for processing the recorded data and assessing the piloting technique;

- to create a computer model to compare the recorded flight parameters with their setpoints.

Another main objective is to create an electronic database for storing information and evaluations of completed flight tasks. In this way, students' personal files can be made electronic.

\section{A computer application model for flight assessment}

The computer application for flight tasks assessment allows, using the records from the flight data recorder of the aircraft, to perform a qualitative analysis of the exercise performed and to evaluate the flight. Each trainee has their own database, which contains all the necessary information about the exercises already completed and the relevant assessment. Based on the evaluation of the completed exercises an overall assessment of the level of preparation achieved can be determined.

The main features of the application are:

- adding data for a new learner;

- removing or editing already existing learner data;

- $\quad$ selection of trainee;

- introduction of data, important in the formation of assessment of the completed exercise;

- analysis of the information recorded by the flight data recorder;

- assessment of the elements performed in the exercise;

- an electronic database of exercises already evaluated;

- calculating the overall assessment of the level of preparation achieved.

Advantages:

- use computerized systems for assessing pilot training;

- instructor staff is facilitated;

- make an objective assessment.

The application allows three choices to be made (Fig. 1):

- selection of a pilot;

- add/remove pilot;

- editing. 


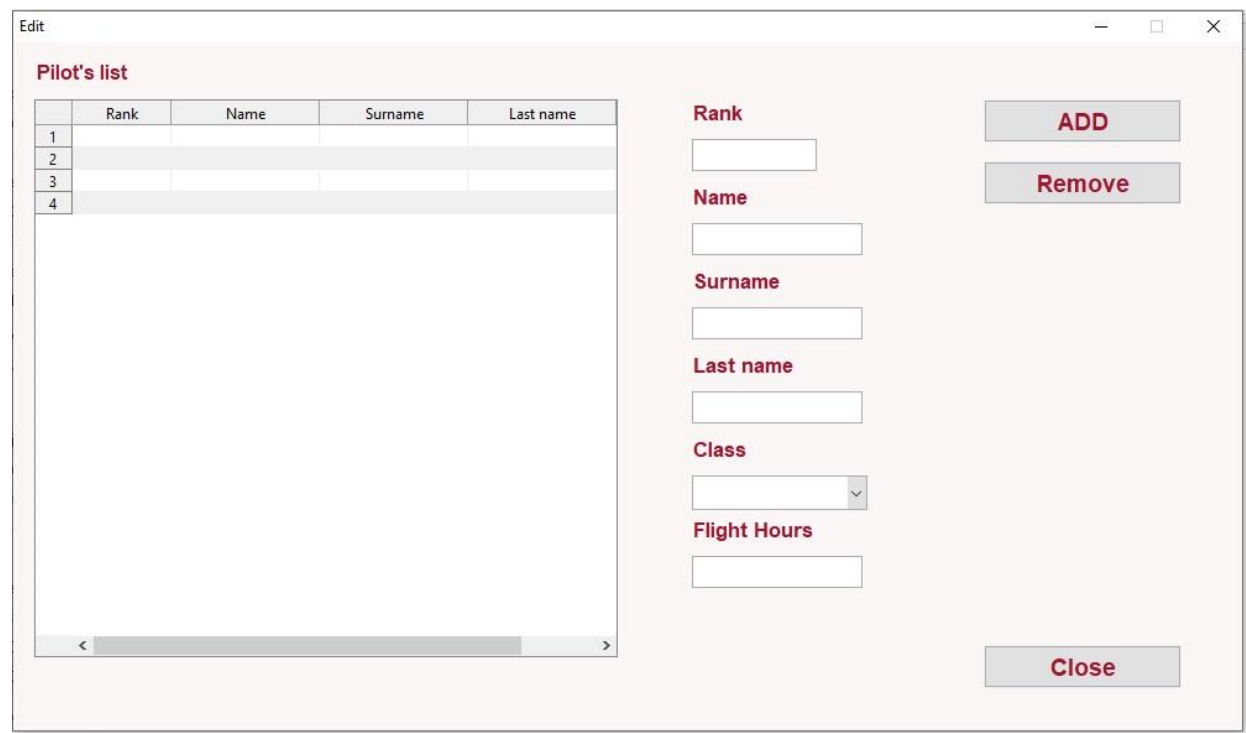

Fig. 1. Pilot's list

The choice of the trainee (pilot) to be assessed is related to the tasks they have already completed (Fig. 2). This information includes:

- exercise name and number and flight number;

- the type of aircraft on which the trainee flies;

- the flight height;

- the area of flight;

- type of flight;

- time of day;

- flight assessment.

The app allows you to add a flight to be evaluated, to remove incorrect information and to make an overall assessment of the level of preparation achieved. All this information is printable. 


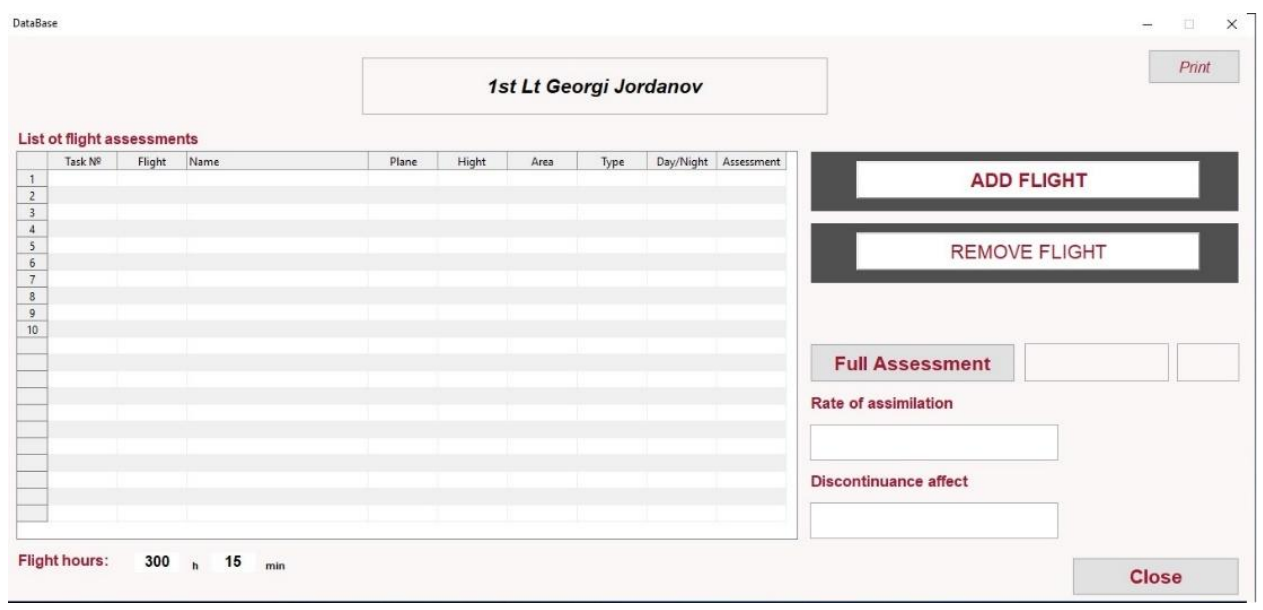

Fig. 2. List of flight assessments

In order to evaluate the elements already selected, the entry from the flight data recorder must be added. This record can be taken in tabular form from the Flight Safety Office. Using this computer application, the recording is processed and presented graphically (Fig. 3). This allows the evaluator to see which the elements are and whether the safety measures are observed [1]. The evaluation of the elements is made by comparing the actual values of the flight parameters with those set by the already adopted evaluation standards (usually speed, load factor and altitude) [2].

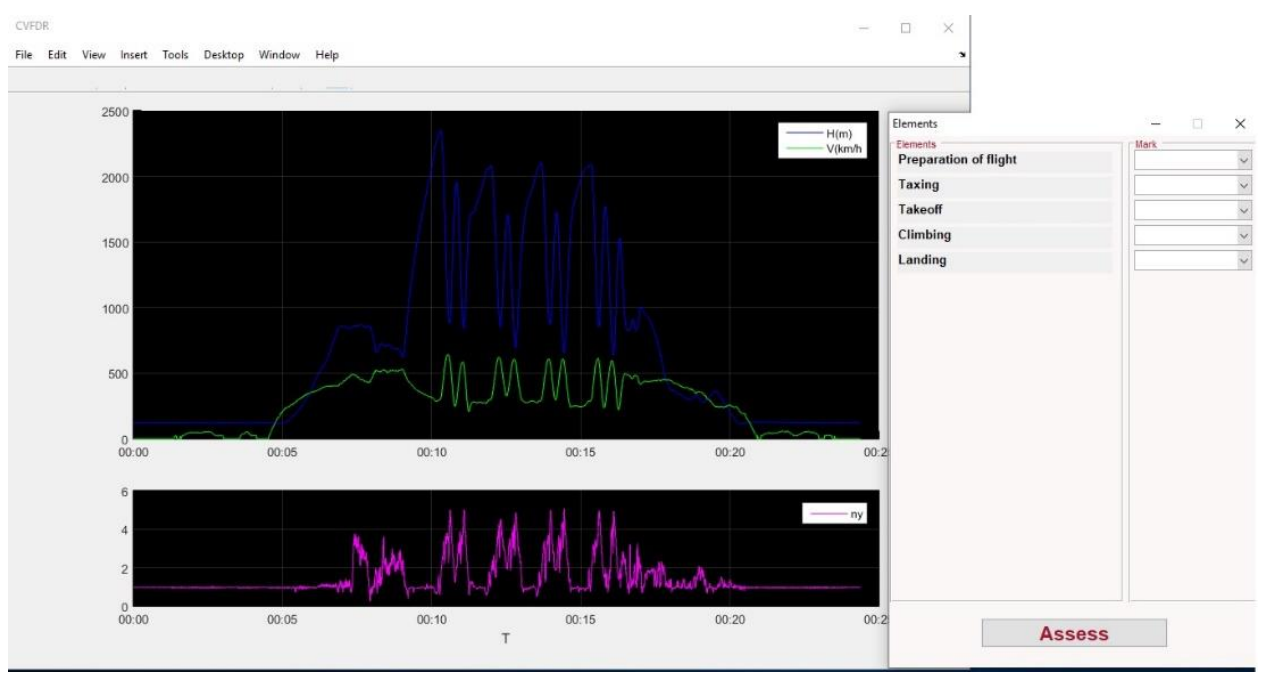

Fig. 3. CVFDR 
Depending on the type of aircraft selected, the evaluator may see the relevant assessment standards.

The flight technique learning rate and the impact of pause are also important for the final assessment, so they can also be added.

When the flight assessment is made, all information is added and recorded in the database of the selected trainee.

For more accuracy during the analysis of the entry, the application allows the graphic to be zoomed in this part of the entry, where the element being evaluated is. Hereby the values of the recorded flight parameters can be determined more easily (Fig. 4).

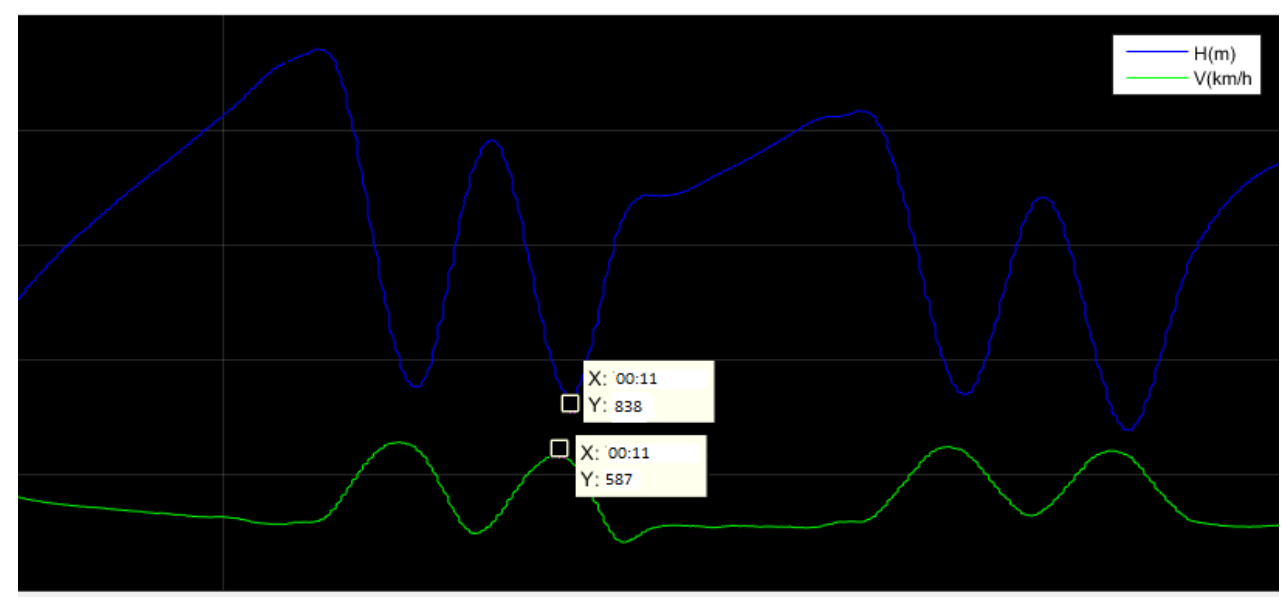

00:10

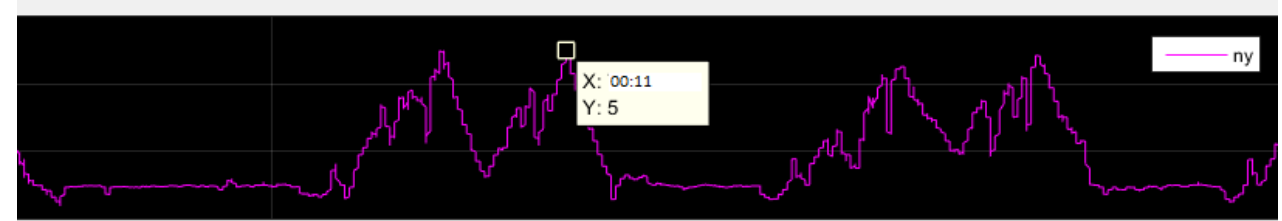

00:10

T

Fig. 4. Flight parameters 

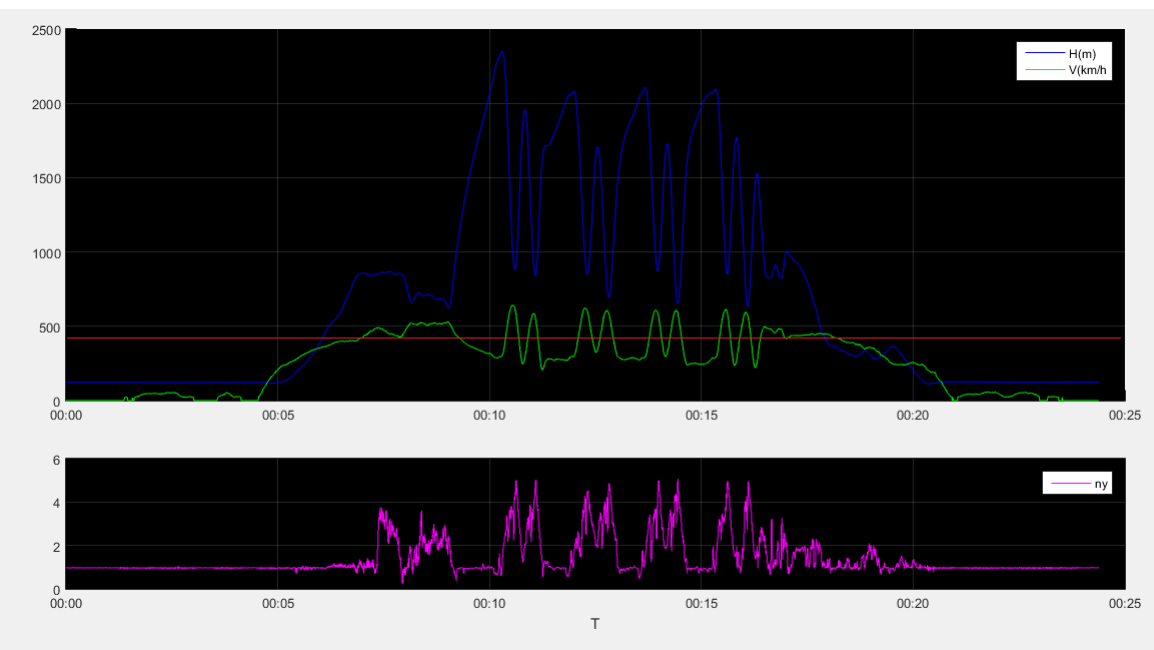

Fig. 5. Minimum safety height

When the area, the height and the type of flight are selected the minimum safety height is automatically determined - red line (Fig. 5). The minimum safety height is one of the important safety features. The minimum safety height can be different depending on the terrain and the pilot's skills. If the minimum safety height is violated, the instructor can see this on the entry, which is important in forming the flight assessment.

\section{Conclusions}

Quantitative evaluation of the piloting technique means the assessment of the pilot's actions in performing the flight elements in the different types of flight training. Unlike qualitative evaluation, in which the completed elements are determined and its main tasks is to determine the deviations and errors of the flight assignment, in the quantitative analysis, an assessment of the important elements of the type of preparation is made, and the main task is to determine their level. In the quantification of the piloting technique, each maneuver is evaluated by comparing the actual parameters for certain stages of the maneuver with recommended speeds, heights and load factor. The average value and the deviation are determined and the tolerances are compared.

\section{References}

1. Chikurtev, D., K. Yovchev, N. Chivarov, and I. Rangelov, Indoor Navigation Using Existing Infrastructure for Professional Service Robots, Advances in Intelligent Systems and Computing, 2019, 980, 231-239, ISBN: 978-303019647-9, ISSN: 2194-5357, DOI:10.1007/978-3-030-19648-6_27. 
2. Chivarov, S, D. Chikurtev, K. Yovchev, and N. Chivarov, Multi-channel software infrastructure for remote control of service robots, 2019, Article number 8820362. ISBN: 978-172810521-5, DOI:10.1109/CoDIT.2019.8820362, 1283-1288.

\section{КОЛИЧЕСТВЕНА ОЦЕНКА НА ТЕХНИКАТА НА ПИЛОТИРАНЕ ПО ЗАПИСИ ОТ РЕГИСТРАТОР НА ПОЛЕТНИ ДАННИ}

\section{А. Маринов, Г. Йорданов, М. Камбушев, С. Билидеров, К. Камбушев}

\section{Резюме}

Оценяването е важна част от процеса на обучение на младия летателен състав, особено в случаите, когато от оценката зависи разпределението на обучаемите на самолет или вертолет. Оценяването на техниката на пилотиране в началния етап определя до каква степен обучаемите имат потенциал да възприемат, научат и осмислят новата за тях материя, и до каква степен успяват да приложат своите знания. Оценяването е пряко свързано с качеството на обучение, а оценката трябва да покаже на обучаемите пропуските, които допускат, а също и да ги стимулира да надграждат своите знания и умения. Обучаемите трябва да са добре запознати с методиката за оценяване и да разбират нейната цел, в противен случай, обучаемият остава с впечатлението, че получените оценки не са показател за техните знания и умения. 